\title{
NFIC wt Allele
}

National Cancer Institute

\section{Source}

National Cancer Institute. NFIC wt Allele. NCI Thesaurus. Code C53094.

Human NFIC wild-type allele is located in the vicinity if 19p13.3 and is approximately 104 $\mathrm{kb}$ in length. This allele, which encodes nuclear factor $1 \mathrm{C}$-type protein, plays a role in both the modulation of transcription by RNA polymerase II and the activation of DNA replication. 